Death Valley: GEOLOGY, ECOLOGY, ARCHAEOLOGY 


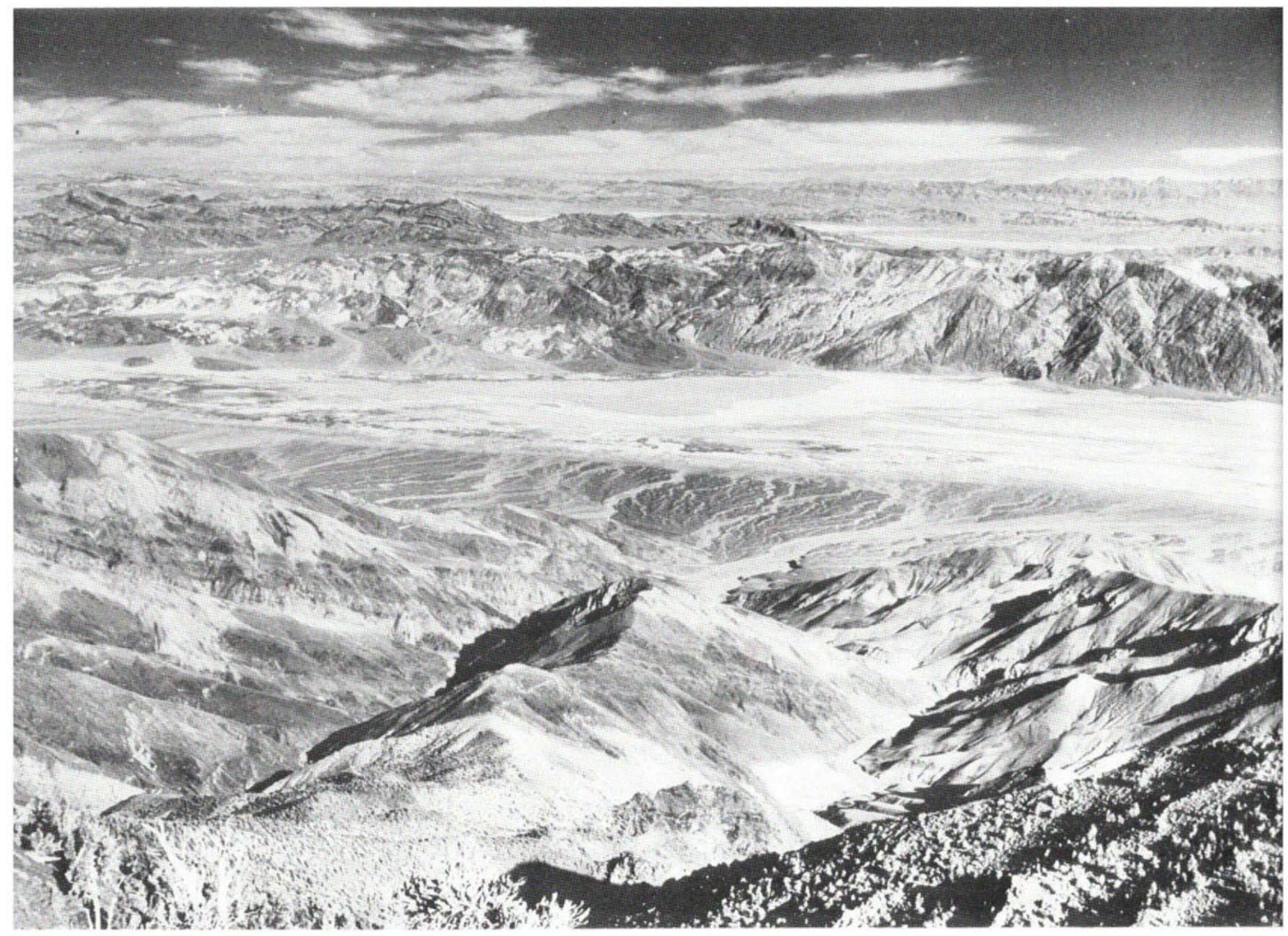


Charles B. Hunt

\section{Death Valley}

\section{GEOLOGY, ECOLOGY, ARCHAEOLOGY}

UNIVERSITY OF CALIFORNIA PRESS

Berkeley Los Angeles London 
University of California Press

Berkeley and Los Angeles, California

University of California Press, Ltd

London, England

Copyright $\odot 1975$ by The Regents of the University of California

ISBN 0-520-03013-3

Library of Congress Catalog Card Number: 74-84094

Designed by Harlean Richardson

Printed in the United States of America

23456789

\section{FRONTISPIECE:}

The Basin and Range Province, of which Death Valley is a part, consists of broad, down-faulted valleys between block-faulted mountains. This view, northeast from Telescope Peak, shows the east slope of the Panamint Range in the foreground, and gravel fans built of debris eroded from the mountains sloping to the floor of Death Valley. Beyond is the faulted front of the Black Mountains (right) and Funeral Mountains (left). On the skyline is the Amargosa Desert and block-faulted mountains in and around it. (Photograph by Warren B. Hamilton.) 
Affectionately dedicated to Matt and Rosemary Ryan, formerly of the Park Service, known to their many friends as Mr. and Mrs. Death Valley 
